\title{
Bacillus thuringiensis in caterpillars and associated materials collected from protected tropical forests in northwestern Costa Rica
}

\author{
César Rodríguez-Sánchez ${ }^{1,2}$, Ana Sittenfeld ${ }^{1,4 *}$, Daniel H. Janzen ${ }^{5}$ \& Ana M. Espinoza ${ }^{1,3}$ \\ 1 Centro de Investigación en Biología Celular y Molecular, Universidad de Costa Rica, Ciudad Universitaria Rodrigo \\ Facio, San José, Costa Rica. \\ 2 Present Address: Fachbereich Biologie/Chemie. Abteilung Mikrobiologie, Universität Osnabrück. Barbarastr.11. D- \\ 49069, Osnabrück. Germany. rodriguez@biologie.uni-osnabrueck.de \\ 3 Escuela de Fitotecnia, Facultad de Agronomía, Universidad de Costa Rica, Ciudad Universitaria Rodrigo Facio, San \\ José, Costa Rica. \\ 4 Facultad de Microbiología Universidad de Costa Rica, Ciudad Universitaria Rodrigo Facio, San José, Costa Rica. \\ 5 Department of Biology, University of Pennsylvania, Philadelphia, 19104. USA. \\ * Corresponding author: Tel.:+506-207 3194; Fax.:+506 207 3190; sitten@racsa.co.cr
}

\section{Received 16-VII-2004. Corrected 08-VIII-2005. Accepted 07-XI-2005.}

\begin{abstract}
Bacillus thuringiensis (Bt) synthesizes crystalline inclusions that are toxic to caterpillars (Lepidoptera) and other orders of invertebrates. Materials associated with 37 caterpillars from 16 species, collected while feeding on 15 different species of host plants in dry, cloud and rain forests located in the Área de Conservación Guanacaste in northwestern Costa Rica, were examined for the presence of Bt. From a total of 101 derived samples, $25 \mathrm{Bt}$ isolates were cultured: $56 \%$ from host plant leaves, $8 \%$ from caterpillar guts and $36 \%$ from caterpillar fecal pellets. $B t$ was isolated from at least one sample in $38 \%$ of the systems constituted by the food plant, gut and fecal pellets corresponding to a single caterpillar. Four different morphologies of crystalline inclusions were observed, with bipyramidal and irregular crystal morphologies being the most prevalent. Rev. Biol. Trop. 54(2): 265-271. Epub 2006 Jun 01.
\end{abstract}

Key words: Bacillus thuringiensis, caterpillars, food plants, insect guts, fecal pellets, conserved wildlands.

Caterpillars are predominantly plant-eating insects of tropical living foliage (Schultz 2002). They consume many different species of bacteria and fungi derived, among other sources, from soil, fecal material and decomposed remains from conspecifics and other species of animals that come in contact with the foliar materials they ingest. This horizontally acquired, as well as vertically transmitted microbial community established within their guts, is known to play a vital role in their nutrition, development, reproduction and fecundity (Cruden et al. 1987, Dow 1992, Harris 1993, Giron et al. 1995, Cazemier et al. 1997). The gut cavity of a caterpillar is a complex microhabitat with respect to nutrients, toxins, oxygen levels, speed of transit, $\mathrm{pH}$ and redox potentials (Dow 1992, Johnson and Felton 1996, Johnson and Barbehennb 2000). Despite all these sources of heterogeneity, once in the gut, a given microbe could be considered either a resident that multiplies on the resources available, a waif passing through in an act of dispersal, or an entomopathogen that gains yet more resources by killing the insect.

Some of the $\delta$-endotoxins (Cry proteins) and Cyt proteins from Bacillus thuringiensis $(B t)$ exhibit high toxicity and specificity against insects, some parasitic nematodes, mites and protozoa (Schnepf and Crickmore 1998). The hemolymph and carcasses of such susceptible insects constitute a favorable environment for 
the growth of $B t$ populations (Aronson et al. 1986). On the other hand, some $\delta$-endotoxins have not yet been associated with insecticidal action, but with other interesting biological activities (Misuki et al. 1999). Bt has been isolated from many sources, e.g., from soil (De Lucca et al. 1981, Ohba and Aizawa 1986), live and dead insects (Damgaard et al. 1998), stored grains (Meadows et al. 1992), foliar surfaces (Smith and Couche 1991, Misuki et al. 1999), water bodies (Ichimatzu et al. 2000), marine sediments (Maeda et al. 2000) and activated sludge (Misuki et al. 2001). The widespread distribution of apparently dormant $B t$ in nature (Martin and Travers 1989), the ecological roles it may play in soil ecosystems and the potential interactions of this microorganism with caterpillars in tropical forests are still poorly understood issues. In preliminary experiments (Sittenfeld et al. 2002), Bt has been isolated from midgut of Automeris zugana caterpillars collected in the Área de Conservación Guanacaste in northwestern Costa Rica (Janzen 2000). This study reports on the isolation of $B t$ from caterpillar guts, fecal pellets and host plants collected in different protected ecosystems (dry, rain and cloud tropical forests) as a contribution to the better understanding of $B t$ ecology in relation to lepidopterans in wildland environments.

\section{MATERIALS AND METHODS}

Sampling. Caterpillars and their food plants were collected through random search in trees and bushes located in tropical dry forests (Santa Rosa and Los Almendros at 200-300 masl), a cloud forest (Cacao at 1000 masl) and a rain forest (San Cristóbal at 500-600 masl) in the Área de Conservación Guanacaste (ACG). All caterpillars were separately put into a new plastic bag in situ with plenty of foliage from the same plant where the specimen was found. Bags were transported by ground to rearing barns in the Administration Area in the sector of Santa Rosa in the ACG and hung for 2448 hours in order to simultaneously evaluate the viability of the individuals collected and to obtain larval excrement at the bottom of each bag. All caterpillars appeared active and healthy at the moment of collection and their feeding activity and survival remained constant during the 48 hours they were kept in captivity before sacrifice. Each caterpillar collected from a single host plant was treated as an individual set of gut and fecal material.

Foliar material and larval excrement cultures. Approximately 3-5 leaves and 1-3 g of fecal pellets from each bag were separately inoculated in $10 \mathrm{ml}$ of Luria Bertani (LB) broth. Leaves were aseptically sectioned into ca. $0.25 \mathrm{~cm}^{2}$ pieces prior to inoculation, and fecal pellets were macerated inside the tube and homogenized to increase contact of the material with the culture media.

Larval dissection and gut culture. Caterpillars were killed by placing them separately for $15-30 \mathrm{~min}$ at $-20^{\circ} \mathrm{C}$. The external surface was disinfected through sequential washes with $0.2 \mu \mathrm{m}$ filter-sterilized $70 \%$ Ethanol (2 min), a mix of $5.25 \%$ sodium hypochloride and $0.1 \%$ Tween 20 (2 min) and several washes with sterile distilled water. As a control for this process, each disinfected caterpillar was rolled on the surface of a LB agar plate, which was later incubated at $30^{\circ} \mathrm{C}$ for five days. Afterwards, the gut from each caterpillar was dissected aseptically in a laminar flow hood, macerated and inoculated along with its contents in $10 \mathrm{ml}$ of LB broth.

Bt identification. After incubation in an aerobic atmosphere at $30^{\circ} \mathrm{C}$ for $48 \mathrm{~h}$, a loopful from each broth was streaked on LB agar plates. Based on colony morphology, a single presumptive $B t$ colony from each plate was selected and obtained in pure culture on Bacillus cereus selective agar plates (Holbrook and Anderson 1980). As a definitive criteria for identification, sporulated cultures of presumptive $B t$ isolates were examined by phase contrast microscopy for the synthesis of crystalline parasporal inclusions. The occurrence of $B t$ isolates was 
analyzed considering each type of material as separate (according to sampling site) and in systems defined by the food plant leaves, gut and fecal pellets associated with each caterpillar collected (Bt-harboring systems).

Crystal inclusions morphology. Smears from sporulated cultures on LB plates were stained for 3-5 min with Coomassie Blue (3.75\% in HOAc-EtOH 95\%) and observed under light microscopy (100X). The morphology of the crystals synthesized by each isolate was recorded after at least three observations on different days.

\section{RESULTS}

A total of 37 caterpillars and 27 samples of food plants representing 16 Lepidoptera species from five insect families (Nymphaliidae, Hesperiidae, Arctiidae, Sphingidae and Notodontidae) and 15 species of food plants from 10 plant families (Simaroubaceae, Asclepiadaceae, Malphigiaceae, Fabaceae, Myrtaceae, Rubiaceae, Poaceae, Melastomataceae, Clusiaceae and Araliacea) were collected (Table 1).

As confirmed by the presence of parasporal crystal inclusions and the phenotypic reaction on $B$. cereus selective agar plates, at least one $B t$ isolate was cultured from $25(24 \%)$ out of 101 samples analyzed. They were isolated from all sample types independently of their origin within the ACG, but mostly from food plant foliage $(56 \%)$ and fecal pellets $(36 \%)$ (Table 1). Further differences were detected in the number and percentages of isolates cultured from leaves and caterpillar guts collected in different ecosystems: it was more frequently cultured from foliar material collected from San Cristóbal and Cacao and from guts of caterpillars collected at San Cristóbal and Los Almendros (Table 2).

$B t$ was isolated from at least one material in $38 \%(\mathrm{n}=14)$ of the systems constituted by the food plant, gut and fecal pellets corresponding to a single caterpillar. Within a system, it was more frequently cultured from both the foliar material and fecal pellets (64\%) than from gut samples (3\%) (Table 1).

Four different morphologies of crystalline inclusions were observed (oval, irregular, bypiramidal and squared), with bipyramidal and irregular crystal morphologies being the most prevalent (20 and $44 \%$ respectively). Nine isolates $(36 \%)$ exhibited a combination of at least two different crystal morphologies (results not shown). Moreover, $B t$ was cultured from the leaves naturally consumed by 3 of 5 monarch caterpillars collected, and in some cases also from their guts or fecal pellets (Table 1).

\section{DISCUSSION}

These results are in accordance with reports where foliar surfaces and insectfavoring habitats have been indicated as frequent sources of $B t$ isolation (Ben-Dov et al. 1997, Bravo et al. 1998, Arrieta et al. 2004). However, this is the first report of $B t$ isolation from fecal pellets of caterpillars collected in tropical protected environments.

The results obtained indicate that non-Btsusceptible caterpillars and possibly $B t$-susceptible caterpillars, contribute directly to the dispersion of this bacterium in the ACG forests. The presence of $B t$ in fecal pellets of caterpillars (Tables 1 and 2), which fall or are washed to the foliage and forest floor below, could allow this bacterium to recirculate in these ecosystems (i.e., from the soil, to the foliage, passed through an insect, and back down to the forest floor), making it part of the horizontally transmitted caterpillar-based microbial community. It is plausible to speculate that the $B t$ population is thinly distributed throughout the habitat, "waiting" to be eaten by a caterpillar (or other insect) in which it will multiply, either lethally or benignly.

The different spatial distribution of $B t$ on the leaves and the fact that it is not possible to collect the same leaf material that the caterpillar has already cut for ingestion, may partially explain why $B t$ was not successfully isolated 
TABLE 1

Isolation of Bacillus thuringiensis from food plants and caterpillar-derived materials collected in the Area de Conservación Guanacaste

\begin{tabular}{|c|c|c|c|c|c|c|}
\hline Code $^{a}$ & $\begin{array}{l}\text { Collection Site } \\
\text { (forest type) }^{b, c}\end{array}$ & Caterpillar & Food Plant & $\begin{array}{c}B t \\
\text { from } \\
\text { leaves }\end{array}$ & $\begin{array}{c}B t \\
\text { from } \\
\text { guts }\end{array}$ & $\begin{array}{c}B t \text { from } \\
\text { fecal } \\
\text { pellets }\end{array}$ \\
\hline
\end{tabular}

\begin{tabular}{|c|c|c|c|c|c|c|}
\hline 00-SRNP-114 & $\mathrm{SC}(\mathrm{RF})$ & Bungalotis diaphorus & Simarouba amara & - & - & - \\
\hline 00-SRNP-424 & $\mathrm{SC}(\mathrm{RF})$ & Danaus plexippus & Asclepias curassavica & + & + & - \\
\hline 00-SRNP-425 & $\mathrm{SC}(\mathrm{RF})$ & Danaus plexippus & Asclepias curassavica & + & - & - \\
\hline 00-SRNP-426 & $\mathrm{SC}(\mathrm{RF})$ & Danaus plexippus & Asclepias curassavica & - & - & - \\
\hline 00-SRNP-427 & $\mathrm{SC}(\mathrm{RF})$ & Enosis 00 -SRNP-427 a & Poaceae DHJ14172 a & + & - & + \\
\hline 00-SRNP-428 & $\mathrm{SC}(\mathrm{RF})$ & Enosis $00-\mathrm{SRNP}-427^{\mathrm{a}}$ & Poaceae DHJ14172a & - & - & - \\
\hline 00-SRNP-429 & $\mathrm{SC}(\mathrm{RF})$ & Enosis $00-\mathrm{SRNP}-427^{\text {a }}$ & Poaceae DHJ14172 a & + & - & + \\
\hline 00-SRNP-437 & $\mathrm{SC}(\mathrm{RF})$ & Danaus plexippus & Asclepias curassavica & + & - & + \\
\hline 00-SRNP-438 & $\mathrm{SC}(\mathrm{RF})$ & Danaus plexippus & Asclepias curassavica & - & - & - \\
\hline 00-SRNP-544 & $\mathrm{SC}(\mathrm{RF})$ & Cephise nuspesez & Hiraea sp. & + & - & + \\
\hline 00-SRNP-545 & $\mathrm{SC}(\mathrm{RF})$ & Cephise nuspesez & Hiraea sp. & + & - & - \\
\hline 00-SRNP-546 & $\mathrm{SC}(\mathrm{RF})$ & Morpho peleides & Lonchocarpus oliganthus & - & - & - \\
\hline 00-SRNP-547 & $\mathrm{SC}(\mathrm{RF})$ & Parelbella macleannani & Eugenia basilaris & - & - & - \\
\hline 00-SRNP-548.01 & $\mathrm{SC}(\mathrm{RF})$ & Actinote leucomel & Mikania DHJ14177 a & - & - & - \\
\hline 00-SRNP-548.02 & $\mathrm{SC}(\mathrm{RF})$ & Actinote leucomel & Mikania DHJ14177 a & - & - & - \\
\hline 00-SRNP-548.03 & $\mathrm{SC}(\mathrm{RF})$ & Actinote leucomel & Mikania DHJ14177 a & - & - & - \\
\hline 00-SRNP-548.04 & $\mathrm{SC}(\mathrm{RF})$ & Actinote leucomel & Mikania DHJ14177 a & - & - & - \\
\hline 00-SRNP-548.05 & $\mathrm{SC}(\mathrm{RF})$ & Actinote leucomel & Mikania DHJ14177 a & - & - & - \\
\hline 00-SRNP-548.06 & $\mathrm{SC}(\mathrm{RF})$ & Actinote leucomel & Mikania DHJ14177 a & - & - & - \\
\hline 00-SRNP-548.07 & $\mathrm{SC}(\mathrm{RF})$ & Actinote leucomel & Mikania DHJ14177 a & - & - & - \\
\hline 00-SRNP-548.08 & $\mathrm{SC}(\mathrm{RF})$ & Actinote leucomel & Mikania DHJ14177 a & - & - & - \\
\hline 00-SRNP-548.09 & $\mathrm{SC}(\mathrm{RF})$ & Actinote leucomel & Mikania DHJ14177 a & - & - & - \\
\hline 00-SRNP-548.10 & $\mathrm{SC}(\mathrm{RF})$ & Actinote leucomel & Mikania DHJ14177 a & - & - & - \\
\hline 00-SRNP-548.11 & $\mathrm{SC}(\mathrm{RF})$ & Actinote leucomel & Mikania DHJ14177 a & - & - & - \\
\hline 00-SRNP-2339 & LA (DF) & Aellopos fadus & Genipa americana & + & - & + \\
\hline 00-SRNP-2340 & LA (DF) & Urbanus proteus & Centrosema sagittatum & + & - & + \\
\hline 00-SRNP-2341 & LA (DF) & Urbanus proteus & Centrosema sagittatum & - & - & - \\
\hline 00-SRNP-2343 & LA (DF) & $\begin{array}{l}\text { Notodontidae } \\
\text { 00-SRNP-2343 }\end{array}$ & Psychotria valeriana & - & + & - \\
\hline 00-SRNP-2344 & $\mathrm{LA}(\mathrm{DF})$ & Bungalotis erythus & Schefflera morototoni & - & - & - \\
\hline 00-SRNP-2348 & LA (DF) & Chioides cattilus & Rhynchosia calycosa & + & - & + \\
\hline 00-SRNP-6102 & $\mathrm{SR}(\mathrm{DF})$ & Bungalotis quadratum & Inga vera & - & - & - \\
\hline 00-SRNP-6179 & $\mathrm{SR}(\mathrm{DF})$ & Telemiades fides & Inga vera & - & - & - \\
\hline 00-SRNP-6228 & SR (DF) & Telemiades fides & Inga vera & + & - & + \\
\hline 00-SRNP-9031 & $\mathrm{C}(\mathrm{CF})$ & Coloradia marathusa & Miconia lonchophylla & + & - & - \\
\hline 00-SRNP-9032 & $\mathrm{C}(\mathrm{CF})$ & Coloradia marathusa & Miconia lonchophylla & + & - & - \\
\hline 99-SRNP-17124 & $\mathrm{C}(\mathrm{CF})$ & Pyrrhopyge cosyra & Chrysochlamys glauca & + & - & + \\
\hline
\end{tabular}

a Janzen and Hallwachs, 2002. b SC: San Cristóbal, LA: Los Almendros, SR: Santa Rosa, C: Cacao. c DF: Dry forest, CF: Cloud forest, RF: Rain forest. 
TABLE 2

Occurrence of $\mathrm{Bt}$ on food plants, caterpillar guts and fecal pellets among dry, cloud and rain forests located at the ACG

\begin{tabular}{|c|c|c|c|c|c|c|c|c|}
\hline & \multicolumn{2}{|c|}{$\begin{array}{c}\text { Rain Forest } \\
\text { (San Cristóbal) }\end{array}$} & \multicolumn{2}{|c|}{$\begin{array}{c}\text { Dry Forest } \\
\text { (Los Almendros) }\end{array}$} & \multicolumn{2}{|c|}{$\begin{array}{c}\text { Dry Forest } \\
\text { (Santa Rosa) }\end{array}$} & \multicolumn{2}{|c|}{$\begin{array}{l}\text { Cloud Forest } \\
\text { (Cacao) }\end{array}$} \\
\hline & $B t$ isolates & $\begin{array}{l}\text { Samples } \\
\text { analyzed }\end{array}$ & $B t$ isolates & $\begin{array}{l}\text { Samples } \\
\text { analyzed }\end{array}$ & $B t$ isolates & $\begin{array}{l}\text { Samples } \\
\text { analyzed }\end{array}$ & $B t$ isolates & $\begin{array}{l}\text { Samples } \\
\text { analyzed }\end{array}$ \\
\hline $\begin{array}{l}\text { Food } \\
\text { plants }\end{array}$ & $7(50 \%)$ & 14 & $3(43 \%)$ & 7 & $1(33 \%)$ & 3 & $3(100 \%)$ & 3 \\
\hline Guts & $1(4 \%)$ & 24 & $1(15 \%)$ & 7 & $0(0 \%)$ & 3 & $0(0 \%)$ & 3 \\
\hline $\begin{array}{l}\text { Fecal } \\
\text { pellets }\end{array}$ & $4(17 \%)$ & 24 & $3(43 \%)$ & 7 & $1(33 \%)$ & 3 & $1(33 \%)$ & 3 \\
\hline
\end{tabular}

from all of the three materials of the system constituted by the food plant, gut and fecal pellets corresponding to a single caterpillar. A similar observation applies for the fecal pellets; in this case the sample used for culturing represented only a portion from both the leaf material digested and the total number of fecal pellets excreted during the time the caterpillars remained in captivity.

The low recovery of $B t$ from gut samples in spite of a higher prevalence in fecal pellet cultures is puzzling. This could be explained by intraluminal competition from other bacterial species, which could somehow keep the $B t$ population low until it passed from the gut to the fecal pellets (Takatsuka and Kunimi 2000), by abiotic inhibitory effects within the gut cavity (Luthy et al. 1985, Pang and Grigorten 1998), by simple dormancy of the $B t$ population while passing through the gut, or by an accumulation of $B t$ spores in fecal pellets due to the high speed of transit.

Since molecular-based methods were not considered, the observed frequency of $B t$ isolates could have been underestimated. In addition, individuals affected by the action of the delta endotoxins were not detected during the search for caterpillars in the foliage and could have caused a misrepresentation of $B t$ in the samples. In regard to the dynamics of $B t$ within insect guts, it is still necessary to conduct research in regards to the transit rate of $B t$ and quantitatively estimate its density and metabolic stage (UFC/g of gut or $\mathrm{UFC} / \mathrm{cm}^{2}$ of vegetative cells or endospores) on the different materials through time.

All $B t$ isolates derived from a $B t$-harboring system synthesized crystals of the same morphology, suggesting that the isolates recovered from the guts or fecal pellets are similar to the ones ingested on the leaves. In addition, the coexistence of more than one crystal type within a strain could have consequences on the constitution and stability dynamics of insect populations, and could eventually be a factor in the appearance of $B t$-resistant insects.

The use of insect-protected transgenic crops incorporating $B t$ toxins has provided effective tools for the control of a variety of insect pests. However, populations of non-target insect species belonging to the same order as the target pest might be affected as well. Initial concerns about the effects of pollen from $B t$ transgenic crops on the larvae of the monarch (Danaus plexippus) and black swallowtail (Papilio polyxenes) butterflies have raised a controversy about the use of this kind of insecticide (Losey 1999, Maeda et al. 2000). In this study, the presence of $B t$ in tropical protected forests in the ACG, located over a hundred kilometers from areas where $B t$ is sprayed on crop fields (at present, no transgenic crops are authorized for commercial purposes in Costa Rica) was demonstrated. The apparent lack of toxicity of these isolates to their host caterpillars (collected alive and active) might be explained 
by either a low prevalence of cryI genes in these wild $B t$ populations, a natural resistance to $B t$, or by a combination of both. The effects of $B t$-based pesticides on the survival and physiological traits of caterpillars (such as weight gain) have not been previously studied under field conditions in wildlands of tropical environments, and it remains to be determined, as $B t$ might be one of the many natural mechanisms that maintains a delicate balance among insect populations in tropical forests.

\section{ACKNOWLEDGMENTS}

The authors wish to express their gratitude to the staff of the ACG for providing logistics and support to the project. This work was supported in part by grants Ref 3-208-99 and 16300-FI from CONICIT, San José, Costa Rica, by grant VI 801-99-506 from Vicerrectoría de Investigación, Universidad de Costa Rica, and facilitated by NSF DEB 9400829, DEB 9705072 and NSF 84224.

\section{RESUMEN}

Bacillus thuringiensis $(B t)$ sintetiza inclusiones cristalinas que resultan tóxicas para algunas larvas de lepidópteros y otros órdenes de invertebrados. Su presencia fue examinada en materiales asociados a 37 orugas de mariposas de 16 especies, las cuales fueron colectadas mientras se alimentaban en 15 especies diferentes de plantas hospederas en bosques secos, nubosos y húmedos localizados dentro del Área de Conservación Guanacaste (ACG) en el noroeste de Costa Rica. A partir de un total de 101 muestras se obtuvo 25 aislamientos de $B t: 56 \%$ a partir de material foliar de las plantas hospederas, $8 \%$ a partir del contenido intestinal de las larvas y $36 \%$ a partir de sus excrementos. Esta bacteria fue cultivada a partir de al menos uno de los 3 diferentes tipos de muestra asociados a una oruga particular (planta hospedera, intestino, excremento) en $38 \%$ de los casos posibles. En la colección de aislamientos obtenida se observaron cuatro morfologías de inclusiones cristalinas, siendo aquellas bipiramidales e irregulares las más prevalentes.

Palabras clave: Bacillus thuringiensis, larvas de mariposa, plantas hospederas, tractos intestinales de insectos, material fecal, áreas protegidas.

\section{REFERENCES}

Arrieta, G., A. Hernández \& A.M. Espinoza. 2004. Diversity of Bacillus thuringiensis strains isolated from coffee plantations infested with the coffee berry borer Hypothenemus hampei. Rev. Biol. Trop. 52: 757-764.

Aronson, A., W. Beckman \& P. Dunn. 1986. Bacillus thuringiensis and related insect pathogens. Microbiol. Rev. 50: 1-24.

Ben-Dov, E., A. Zaritsky, E. Dahan, Z. Barak, R. Sinai, R. Manasherob, A. Khamraev, E. Troitskaya, A. Dubitsky, N. Berezina \& Y. Margalith. 1997. Extended screening by PCR of seven cry-group genes from field collected strains of Bacillus thuringiensis. Appl. Environ. Microbiol. 63: 4883-4890.

Bravo, A., S. Sarabia, L. López, H. Ontiveros, C. Abarca, A. Ortiz, M. Ortiz, L. Lina, F. Villalobos, G. Peña, M. Nuñez-Valdez, M. Soberón \& R. Quintero. 1998. Characterization of cry genes in a Mexican Bacillus thuringiensis strain collection. Appl. Environ. Microbiol. 62: 4965-4972.

Cazemier, A.E, J.H.P. Hackstein, H.J.M. Op den Camp, J. Rosenberg \& C. Van der Drift. 1997. Bacteria in the intestinal tract of different species of arthropods. Microb. Ecol. 33: 189-197.

Cruden, D.L \& A.J. Markovetz. 1987. Microbial ecology of the cockroach gut. Annu. Rev. Microbiol. 41: 617-643.

Damgaard, P.H., A. Abdel-Hameed, J.C. Pedersen \& J. Eilenberg. 1998. Natural occurrence of Bacillus thuringiensis on cabbage foliage and in insects associated with cabbage crops. J. Appl. Microbiol. 82: 253-258.

De Lucca, A.J., J.G. Simonson \& A.D. Larson . 1981. Bacillus thuringiensis distribution in soils of the United States. Can. J. Microbiol. 27: 865-870.

Dow, J. 1992. pH gradients in Lepidopteran midgut. J. Exp. Biol. 172: 355-375.

Girin, C. \& M. Larson. 1995. Microorganism variation in host infestation efficiency in a parasitoid wasp, Trichogramma bourachae (Hymenoptera: Trichogrammatidae). Experientia 51: 398-401.

Harris, J.M. 1993. The presence, nature and role of gut microflora in aquatic invertebrates: a synthesis. Microb. Ecol. 25: 195-231.

Holbrook, R. \& J.M. Anderson. 1980. An improved selective and diagnostic medium for the isolation 
and enumeration Bacillus cereus in foods. Can. J. Microbiol. 26: 753-759.

Ichimatsu, T., E. Mizuki \& K. Nishimura. 2000. Ocurrence of Bacillus thuringiensis in fresh waters of Japan. Curr. Microbiol. 40: 217-220.

Janzen, D.H. 2000. Costa Rica's Area de Conservación Guanacaste: a long march to survival through nondamaging biodevelopment. Biodiversity 1: 7-20.

Johnson, K. \& R. Barbehennb. 2000. Oxygen levels in the gut lumens of herbivorous insects. J. Insect. Physiol. 46: 897-903.

Johnson, K.S. \& G.W. Felton. 1996. Physiological and Dietary Influences on Midgut Redox Conditions in Generalist Lepidopteran Larvae. J. Insect. Physiol. 42: 191-198.

Losey, J.E. 1999. Transgenic pollen harms monarch larvae. Nature 399: 214.

Luthy, P., C. Hofmann \& F. Jaquet. 1985. Inactivation of $\delta$ endotoxin of Bacillus thuringiensis by tannin. FEMS. Microbiol. Lett. 28: 31-33.

Maeda, M., E. Mizuki \& Y. Nakanura. 2000. Recovery of Bacillus thuringiensis from marine sediments of Japan. Curr. Microbiol. 40: 418-422.

Martin, P. \& R. Travers. 1989. Worldwide abundance and distribution of Bacillus thuringiensis isolates. Appl. Environ. Microbiol. 55: 2437-2442.

Meadows, M.P., D.J. Ellis, J. Butt, P. Jarrett \& H.P. Burges. 1992. Distribution, frequency and diversity of Bacillus thuringiensis in an animal feed mill. Appl. Environ. Microbiol. 58: 1644-1350.

Mizuki, E., T.S.H. Ichimatsu, Y.S. Hwang, H. Park, K. Saitoh, M. Higuchi \& M. Ohba. 1999. Ubiquity of Bacillus thuringiensis on phylloplanes of arboreuous and herbaceous plants in Japan. J. Appl. Microbiol. 86: 979-984.

Mizuki, E., M. Maeda \& R. Tanaka. 2001. Bacillus thuringiensis: A common member of microflora in activated sludges of a sewage treatment plant. Curr. Microbiol. 42: 422-425.
Mizuki, E., M. Ohba, T. Akao, S. Yamashita, H. Saitoh \& Y.S. Park. 1999. Unique activity associated with noninsecticidal Bacillus thuringiensis inclusions: in vitro cell-killing action on human cancer cells. J. Appl. Microbiol. 86: 92-96.

Ohba, M. \& K. Aizawa. 1986. Insect toxicity of Bacillus thuringiensis isolated from soils of Japan. J. Invertebr. Pathol. 47: 12-20.

Pang, A. \& L. Gringorten. 1998. Degradation of Bacillus thuringiensis $\delta$-endotoxin in host insect gut juice. FEMS. Microbiol. Lett. 167: 281-285.

Poppy, G. 2000. GM crops: environmental risks and nontarget effects. Trends. Plant. Sci. 5: 4-6.

Schnepf, E. \& N. Crickmore. 1998. Bacillus thuringiensis and its pesticidal crystal proteins. Microbiol. Mol. Biol. Rev. 62: 775-806.

Schultz, J.C. 2002. How plants fight dirty. Nature 416: 267.

Sittenfeld, A., L. Uribe-Lorío, M. Mora, V. Nielsen, G. Arrieta \& D.H. Janzen. 2002. Does a polyphagous caterpillar have the same gut microbiota when feeding on different species of food plants? Rev. Biol. Trop. 50: 547-560.

Smith, R. \& G. Couche. 1991. The phylloplane as a source of Bacillus thuringiensis variants. Appl. Environ. Microbiol. 57: 311-315.

Takatsuka, J. \& Y. Kunimi. 2000. Intestinal bacteria affect growth of Bacillus thuringiensis in larvae of the oriental tea tortrix, Homona magnanima Diakonoff (Lepidoptera: Tortricidae). J. Invertebr. Pathol. 76: 222-226.

Thomas, D., J. Alun, W. Morgan, J. Whipps \& J. Saunders. 2000. Plasmid transfer between the Bacillus thuringiensis subspecies kurstaki and tenebrionis in laboratory culture, soil and in Lepidopteran and Coleopteran larvae. Appl. Environ. Microbiol. 66: 118-124.

Travers, R., P.A. Martin \& C.F. Reicheldelfer. 1987. Selective process for efficient isolation of soil Bacillus spp. Appl. Environ. Microbiol. 53: 1263-1266. 
